\section{IMF Working Paper}

CC 1998 International Monetary Fund
This is a Working Paper and the author(s) would welcome any comments on the present text. Citations should refer to a Working Paper of the International Monetary Fund. The views expressed are those of the author(s) and do not necessarily represent those of the Fund.

$\mathrm{WP} / 98 / 58$

INTERNATIONAL MONETARY FUND

Western Hemisphere Department

\title{
Competitiveness and the Evolution of the Real Exchange Rate in Chile
}

Prepared by Martine Guerguil and Martin Kaufman ${ }^{1}$

Authorized for distribution by Armando S. Linde

April 1998

\begin{abstract}
This paper reviews the evolution of certain price and nonprice competitiveness indicators in Chile and concludes that the pecuniary loss of competitiveness associated with the appreciation of the peso since the late 1980s has been broadly offset by productivity gains and adjustments in factor intensity, particularly in the manufacturing sector. However, there may be limited room for further advances from that point, which gives new prominence to certain policy issues such as structural reforms to increase productivity, a reassessment of the tax treatment of the mining sector, and a rebalancing of the macroeconomic policy mix to dampen speculative capital inflows.
\end{abstract}

JEL Classification Numbers: F31, F41

Keywords: exchange rate, competitiveness, Chile, productivity, Balassa effect

Authors’ E-Mail Address: mguerguil@imf.org; mkaufman@imf.org

${ }^{1}$ We would like to thank Max Alier, Luis Carranza, Nicolás Eyzaguirre, Esteban Jadresic, Armando Linde, Saul Lizondo, Gian-Maria Milesi-Ferretti, Paulo Neuhaus, Jorge Roldós, Evan Tanner, and participants in a seminar held at the Central Bank of Chile in November 1997, for useful comments and suggestions. 


\section{CONTENTS}

Page

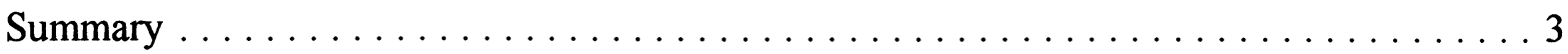

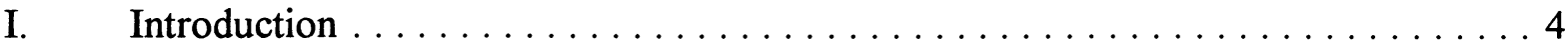

II. Competitiveness and the Real Exchange Rate: Main Conceptual Issues $\ldots \ldots \ldots .4$

III. Real Exchange Rate Indicators $\ldots \ldots \ldots \ldots \ldots \ldots \ldots \ldots \ldots \ldots \ldots$

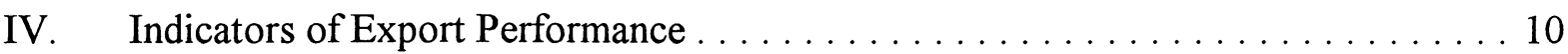

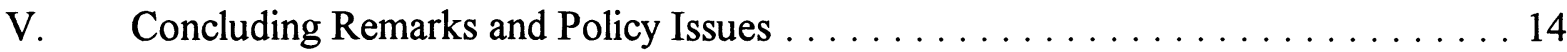

Tables

1. Real Effective Exchange Rates $\quad \ldots \ldots \ldots \ldots \ldots \ldots \ldots \ldots$

2. Real Effective Exchange Rates with Selected Trading Partners . . . . . . 17

3. Market Share in Main Export Markets ................... 18

4. Unit Labor Costs in U.S. Dollars (Value-Added Adjusted) in the Manufacturing Sector .............................. 19

Figures

1. Evolution of the Real Effective Exchange Rate ............... 20

2. Real Effective Exchange Rates with Selected Trading Partners . . . . . . 21

3. Market Share in Main Export Markets . . . . . . . . . . . . 22

4. Export Shares and Export Shares at Constant Exchange Rate . . . . . . . . 23

5. Relative Labor Costs in the Manufacturing Industry ............. 25

References .......................................... 26 


\section{SUMMARY}

The steady real effective appreciation of the Chilean peso since the late 1980s has raised concerns about the country's competitive position, especially with respect to its nontraditional export sectors. However, the relationship between competitiveness and the real exchange rate is a complex one, as movements in the real exchange rate respond to changes in several, often hard to quantify variables.

The evolution of conventional price- and cost-based measures of the real exchange rate during 1980-96 shows a marked depreciation in the 1980 s, followed by a moderate but steady appreciation in the 1990s. A diverging trend is that of the real exchange rate computed with respect to Chile's Latin American partners, which has remained roughly constant in the 1990s.

The increasing share of copper in Chile's exports in recent years signals a higher potential for Dutch disease. An econometric analysis of market shares for noncopper exports suggests that the pecuniary loss of competitiveness related to the currency appreciation was broadly offset by productivity gains and adjustments in factor intensity, particularly in the manufacturing sector. Data on unit labor costs also point to sizable productivity gains in the manufacturing sector.

A continued pattern of real appreciation of the currency could start to weaken the profitability of noncopper activities because intra-firm productivity gains are likely to face decreasing returns, and there may be limited room for further adjustments in factor intensity toward capital-intensive technologies. It is thus important to address a number of policy issues, including structural reforms to increase productivity, reassessing the tax treatment of the mining sector, and rebalancing the macroeconomic policy mix to ease the burden on monetary policy and reduce incentives for speculative portfolio inflows. 


\section{INTRODUCTION}

The steady real effective appreciation of the Chilean peso since the late 1980s has raised concerns about the country's competitive position, especially with respect to its nontraditional export sectors. This paper reviews the evolution of certain price and nonprice competitiveness indicators that may shed light on this issue. Section 2 provides a brief analytical review of the relationship between the real exchange rate and competitiveness. Section 3 examines the evolution of conventional price- and cost-based measures of competitiveness during the period 1980-96. Section 4 discusses the evolution of other indicators of Chile's export performance over the same period, while Section 5 offers concluding remarks.

\section{Competitiveness AND the Real Exchange Rate: Main Conceptual Issues}

The real appreciation of a currency is often interpreted as a loss in competitiveness for the economy. However, the relationship between changes in the competitive position of a country and movements in its real exchange rate (RER) is not as straightforward. A RER appreciation may or may not compromise the competitive stance of a country. In fact, an appreciation may reflect either a loss of competitiveness, when a misalignment situation originates; or an improvement in competitiveness, when the movement in the RER is due to fundamental reasons such as productivity gains. Thus, it is the underlying sources of RER movements which determine whether competitiveness is hurt by, or is itself the cause of the movement in the RER. Competitiveness is affected only when the observed RER departs significantly from its equilibrium value (ERER). A standard practice in the recent literature is to define the RER as the relative price of tradable to nontradable goods, since such price will guide the allocation of resources between sectors to reach internal and external equilibria. In this vein, the ERER could be defined as the RER consistent with equilibrium in the nontradable market in every

period, i.e., $S^{N T}=D^{N T} \forall t$, and intertemporal solvency of the current account (CA), i.e., $C A_{i} \neq 0$ for any $i$ but $\sum_{i}^{\infty} \beta_{i} C A_{i}=0$. The latter is also called the current account sustainability condition, or more generally, the non-Ponzi game condition.

The view that the ERER varies according to its fundamentals in contrast to the static concept posited by the purchasing power parity (PPP) theory ${ }^{2}$ has been well recognized in the literature. The ERER depends on such things as the differential rates of total factor productivity (TFP) growth in the tradables and nontradables sectors, the relative factor endowment of the country, the terms of trade, the taste parameters, the composition of

\footnotetext{
${ }^{2}$ See Balassa (1964) and Samuelson (1964) for a discussion of PPP. It is Harrod (1939) who initially recognized the shortcomings of the PPP theory on grounds of the degree of mobility of goods and production factors.
} 
government expenditures, the tariff structure, the extent of access to capital markets, etc. ${ }^{3}$ In other words, the ERER is determined by both supply and demand side factors.

On the supply side the main determinants of the ERER are the relative TFP growth (usually called the Balassa-Samuelson effect $)^{4}$ and the relative factor endowment of a country: ${ }^{5}$

- The Balassa-Samuelson effect indicates that any process leading to a faster rate of productivity growth in the tradables than in the nontradables sector in a country (compared with the situation in the rest of the world) will induce an ERER appreciation reflecting the increased competitiveness of the economy. The usual explanation assumes a small country with constant-returns-to-scale technologies for both the tradable and nontradable sectors, and the prevalence of the law of one price for the tradable goods and the capital market, i.e., $\mathrm{p}_{\mathrm{T}}=\mathrm{p}_{\mathrm{T}}^{*}$ and $\mathrm{r}=\mathrm{r}^{*}$. Then, an increase in productivity in the production of tradables will tend to increase the marginal productivity of labor in that sector. This will be matched by a rise in wages so that, with perfect labor mobility across sectors, the price of nontradables will increase accordingly, leading to a RER appreciation. This factor is generally recognized as a prime component behind an ERER appreciation. Accelerated structural reforms and market liberalization, as observed in many emerging market economies since the late 1980s, are likely to have led to a significant relative TFP growth vis-à-vis the rest of the world and a currency appreciation that reflects the increased competitiveness of these economies.

- The relative factor endowment argument suggests that countries with significantly different factor endowments will show different nontradable prices (cheaper services in Bhagwati's words) and thus different ERERs. The assertion rests on a stylized 'three-by-two' framework - three goods: one importable, one exportable, and one nontradable; and two factors of production: labor and capital-in which there is more than one cone of diversification and more than one relative factor price. Relatively labor-abundant countries will exhibit lower relative wages and lower nontradable prices. It should be pointed out, though, that capital accumulation will not be translated into continuously higher wages, but will result instead in discrete changes when the country enters a new diversification cone. Hence, the ERER will depend upon the relative factor endowment and the path of capital accumulation, but with step instead of continuous adjustments.

On the side of demand the ERER will appreciate when aggregate demand shifts towards nontradable goods, which can be a result of increased government expenditures, nonhomothetic private preferences - with the assumption that nontradables are luxuries and tradables necessities - or simply changes in tastes of private agents. Nevertheless, these

${ }^{3}$ On this see, for example, Edwards (1989), Harberger (1986), and Neary (1988).

${ }^{4} \mathrm{Hsieh}(1982)$ is regarded as one of the first econometric attempts to identify such effect.

${ }^{5}$ As shown by Bhagwati (1984). 
demand-side effects can be considered to be mostly confined to the short term, since in the long run the adjustment of the capital stock-assumed rather fixed in the short run-will imply, with constant returns to scale, relatively flat supply curves (in which case any demand shift will only affect output composition rather than prices). ${ }^{6}$

Beyond these general considerations, the real appreciation of the currencies of a number of emerging market economies in recent years has prompted renewed interest in several specific factors behind the evolution of RERs, particularly the following:

- The extent of access to foreign capital markets. Capital has flowed to emerging economies in higher volumes in the 1990s. This was in part due to domestic reasons such as the easing of capital account restrictions, credible stabilization and fiscal solvency efforts that led to lower country risk, and the flare-up in profit opportunities induced by comprehensive structural reforms. But it also reflected an exogenous abundance of foreign resources. ${ }^{7}$ The relationship between capital inflows and the appreciation of the RER raises the issue of potential misalignment, but with no straight answer. ${ }^{8}$ With respect to the effect on the ERER, capital inflows may finance an expansion and upgrading of the country's productive capacity leading to direct and indirect productivity gains in the tradable sector, and a rather permanent currency appreciation with no competitive loss. This is because the enhanced productive capacity of the country's tradable sector may permit the future trade balance to exceed the servicing needs of the accumulated debt and the remittances of foreign direct investment. However, inflows may also finance higher consumption (which may overshoot the new permanent income) and low-productivity investment (undertaken under over-optimistic expectations), which will have to be repaid with a reallocation of resources towards tradables, requiring a more depreciated currency in the future. Whether the immediate appreciation exerted by capital inflows exceeds the equilibrium value will depend on the quality and availability of information, the efficiency and accountability of the domestic financial system to intermediate foreign finance, and the degree of exuberance exhibited by players in financial markets. Lack of adequate information, deficient regulatory frameworks, expectations of financial bailouts, and excessive over-optimism contributing to "bubbles" may result in excessive short-term appreciation with attendant competitive losses. However, this risk may be lower in the case of Chile since the external financing has mostly been channeled to capital formation and the financial sector's prudential regulations are stringent.

\footnotetext{
${ }^{6}$ See for example Bergstrand (1991), De Gregorio, Giovannini and Wolf(1993), De Gregorio, Giovannini and Krueger (1993), and Micossi and Milesi-Ferretti (1996).

${ }^{7}$ See for example Frankel and Froot (1990), and Calvo, Leiderman and Reinhart (1993).

${ }^{8}$ The question of the driving forces underlying capital flows also brings out a key distinction between sustainability and intertemporal solvency of the current account. For a discussion of this issue see Milesi-Ferretti (1998).
} 
- "Dutch disease," or the loss of competitiveness suffered by nontraditional export sectors because of currency appreciation resulting from a booming traditional sector. ${ }^{9}$ This is equivalent to a negative pecuniary externality from the traditional to the nontraditional export sector. Thus, the competitive stance of some sectors cannot be appraised without taking into account the negative external effects other sectors can impose on them. In that case, an appreciation of the ERER may still generate problems on two counts. First, if it is perceived that a less-diversified export sector entails more risk to the country's external position (in the absence of hedging policies); and second, when there is the potential danger of a relatively sudden disappearance or severe contraction of the traditional booming exporting sector with potentially severe balance of payment problems-i.e., through technological improvements that turn the exported good obsolete or dispensable. ${ }^{10}$ The issue of potential disappearance hinges on 'time-to-build' arguments for the emergence or reappearance of new export sectors-be it for the accumulation of traditional physical capital or of human capital, including "know-how" - and on potential financial constraints for consumption smoothing during the transition. In the same vein, mining activities tend to make a more intensive use of nontradables during the usually lengthy investment stage (infrastructure building), producing a nonmonotonic RER behavior with a relative appreciating bias during the investment phase. This can exacerbate the Dutch disease effect, since sectors that will be profitable once the investment period is over may severely underinvest or even disappear during the prolonged investment phase, with the consequent costs associated with rebuilding them and the potential weakening of the country's external position.

- The impact of government spending on currency appreciation. Higher government outlays can lead to a more appreciated RER because they will likely produce a net increase in aggregate demand. The magnitude of the effect will depend on the offset coefficient between public and private savings. But even if there is a perfect offset, the different 'tastes' between the public and private sectors can result in a shift in the demand for nontradables and a consequent appreciation. As noted before, this government spending effect should appear, with constant returns to scale, mostly in the short run, where the capital stock is rather fixed. ${ }^{11}$

\section{REAL EXCHANGE RATE INDICATORS}

The real effective exchange rate, which measures the evolution of relative prices and costs denominated in a single currency, remains the most commonly used indicator of

${ }^{9}$ See Corden and Neary (1982) for a detailed discussion of this issue.

${ }^{10} \mathrm{~A}$ textbook example is that of nitrates in Chile early this century.

${ }^{11}$ Several papers have found the government expenditure effect in Chile to be relatively small. See for example Schmidt-Hebbel and Servén (1995), Arellano and Larraín (1996), and Soto and Valdés (1997). 
competitiveness. This indicator, as mentioned before, may either over or understate changes in a country's competitive position. Its practical limitations, related to data pertinence and comparability across countries, have been widely documented. ${ }^{12}$ Nonetheless, it provides a useful first approximation to the issue.

This section examines the behavior of a number of RER indices for the Chilean peso, both at an aggregate level and with respect to the main trading partners. Following common practice, not a single but a battery of indicators are reviewed to gain a better understanding of the various underlying forces at play. The discrimination by trading partners is particularly relevant for an economy like Chile with a relatively diversified export sector. If tradable goods were perfectly homogeneous and standardized commodities, it would be immaterial to consider their origin and destination for the purpose pursued in this section. But if this is not the case and some tradable goods are not perfectly homogeneous, then it is necessary to assess the competitive stance of a country in the light of the situation of its trading partners and potential competitors, as advanced by Armington (1969).

Figure 1 displays the behavior of four alternative measures of the real effective exchange rate for Chile-based on consumer prices, wholesale prices, GDP deflators, and unit labor costs in manufacturing. In each case, foreign prices and costs have been calculated on the basis of a weighted basket of 17 countries that include Chile's main competitors. ${ }^{13}$ All indicators coincide in showing two clear successive trends: a marked depreciation in the 1980s followed by a moderate but steady appreciation in the 1990s. The CPI-based REER depreciated by 58 percent from 1981 to 1988 and then appreciated by 25 percent over the following eight years (Table 1). Changes in the REER based on GDP deflators are broadly of the same magnitude, while those based on the WPI indicator are somewhat less intense (a maximum depreciation of 45 percent followed by a 20 percent appreciation). The movements in the ULC-based REER are more abrupt either way, with a much faster initial depreciation (71 percent) and a more rapid subsequent appreciation (54 percent). In all cases however, the later appreciation is less pronounced than the earlier depreciation, so that by the end of the period (1995 or 1996, according to the indicator) all indices are close to the levels registered in 1985-85.

The evolution of the ratio of the domestic prices of nontradable goods to the prices of tradable goods - often referred to in the literature as the internal real exchange-illustrates

\footnotetext{
${ }^{12}$ See for example Marsh and Tokarick (1994), Turner and Van't dack (1993), Lipschitz and McDonald (1991), and Wickham (1993).

${ }^{13}$ All real effective exchange rate indicators have been computed following the standard Fund methodology according to which: (i) partner country weights are adjusted to take into account third country competition in foreign markets, and (ii) fixed levels of weights are calculated for each trading partner through a double-weighting method applied to bilateral trade flows. For details on this methodology, see Zanello and Desruelle (1997).
} 
trends in internal price competitiveness. The evolution of the internal RER, calculated from sectoral value-added deflators, is shown in Figure 1. It shows the same two successive trends of depreciation followed by appreciation, although with a lesser earlier movement (a depreciation of about 35 percent), followed by an appreciation of about 29 percent in the 1990s.

Figure 2 and Table 2 disaggregate the evolution of the CPI-based REER by trading partners or groups of trading partners. Movements in the REERs with respect to industrial economies mirror relatively closely the movements in the aggregate measure. By contrast, with respect to Latin America the RER exhibits a pattern of lesser depreciation and subsequent relative stability. In the 1980 s the peso depreciated by $60-70$ percent with respect to the industrial countries, but only by 43 percent with respect to Latin America; in the 1990s, it appreciated by 30-40 percent with respect to the OECD, but stayed roughly constant with respect to Latin America. This different trend with respect to Latin America may reflect the regional character of changes in some of the determinants of the region's RERs, including the access to foreign finance and the implementation of market deregulation and comprehensive structural reforms.

In sum, all broad measures considered show that the RER has appreciated in the $1990 \mathrm{~s}$, but that it is still below the 1980-85 levels. This result does not lead to any strong conclusion on the issue of competitiveness, since it is arguable that in the late 1980s the RER was, if anything, undervalued. Also, it is quite likely that the ERER has since appreciated as a result of increased productivity in the tradables sector stemming from the comprehensive structural reforms that have been undertaken. However, when the RER is computed considering exchange rate movements of Latin American partners the result shows an interesting diverging trend: it depreciated in the 1980 s and remained roughly constant since then. This is especially relevant for noncopper exports where the above-mentioned Armington assumption may apply. Further, if it is true that some tradable goods have imperfect substitutes and the Armington assumption matters, then relative productivity differentials should also be evaluated in light of trading partners' performance in that area. Given the recent deregulation and structural reform efforts in several major Latin American partners of Chile, it can be argued that its ERER vis-àvis Latin America has appreciated less (or might even have remained relatively constant) than it did with respect to industrial countries where the rate of productivity growth in the tradables sector is lower. Nonetheless, there is a point where productivity-induced gains in competitiveness may allow exports to enter and compete in higher trade leagues, where goods are still not perfect substitutes, as with commodities, but are subject to stronger competition from more diverse sources. In that case, the Armington assumption will be less relevant and the broad (as opposite to regional) RER would be more appropriate for assessing competitiveness. 


\section{INDICATORS OF EXPORT PERFORMANCE}

This section reviews indicators of export performance that may serve to assess and qualify the impact of the appreciation of the RER described in the previous section. These include changes in export composition, export market shares, and relative unit labor costs. The main finding is that, in the aggregate, manufacturing exports have been able to cope well with the appreciation in the 1990s, but with different effects across sectors. The RER appreciation, partly fueled by a booming copper sector, prompted noncopper sectors to try to compensate for the pecuniary loss in competitiveness through productivity-induced competitive gains, i.e., an inverse Balassa effect (where the direction goes from currency appreciation to productivity gains). Also, those manufacturing sectors with access to more capital-intensive technologies seemed able to cope better with the appreciation by adjusting their factor intensity to the lower relative cost of (mostly imported) capital, replicating the factor intensity of the mining sector.

\section{Export composition}

Chile's export performance through the 1990s has been remarkable. Total exports grew by 11 percent a year, almost twice as fast as in the 1980s. Total export volume also grew by 11 percent on average, and the export-to-GDP ratio rose to 23 percent from 21 percent. An important new trend, however, has been the behavior of copper exports. These showed an average volume growth of 10 percent in the $1990 \mathrm{~s}$, compared to 4 percent in the $1980 \mathrm{~s}$, while volume growth for noncopper exports slowed to 11 percent in the 1990s from 13 percent in the 1980 s. Reverting a previous, decade-long trend of declines, the share of copper in total exports has increased markedly, from 3.5 percent in 1993-94 to over 40 percent in 1996, and it is expected to continue increasing through the coming decade. This reversal is partly due to the introduction in the 1980s of new technological processes that permit the exploitation of low-yield copper deposits at a relatively low cost. ${ }^{14}$ This technological change has fueled higher investment flows (mostly foreign) and significantly altered Chile's factor endowment. As a result, Chile's share of world copper output has grown from 25 percent in 1990 to 34 percent in $1996 .{ }^{15}$ The increased weight of copper in the economy and related capital inflows are likely to have contributed to the appreciation of the peso, which points to the need to pay closer attention to the potential for Dutch disease.

\section{Export market shares}

The evolution of sectoral market shares in a context of currency appreciation can bring additional information on competitiveness. A strong increase in market shares is likely to

\footnotetext{
${ }^{14}$ Known as solvent extraction and electrolytic refining, or SX/EW processes.

${ }^{15}$ Over one third of Chile's refined copper output is produced through the SX/EW processes, compared with 9 percent worldwide.
} 
reflect productivity gains, which may themselves be causing the appreciation or be induced by the appreciation to maintain competitiveness. However, a flat trend in market share may also reflect attempts by domestic producers to maintain their foreign market position by raising productivity (which may face rapidly decreasing marginal returns), and possibly squeezing profit margins (given sunk capital). An unsustainable reduction of profits will obscure in the short term the true deterioration in competitiveness and may lead to an overestimation of productivity gains. However, any country undergoing comprehensive structural reforms is likely to go through a process of sectoral shifts with some sectors expanding and others contracting or even disappearing. This would become a source of concern only if the dislocations in the economy posed balance of payment problems.

Figure 3 and Table 3 show the evolution of Chile's export market share with respect to its main trading partners. They suggest that since the mid-1980s Chile has continuously increased its overall export market share. This trend holds even excluding trade in copper and copper products, pointing to productivity-induced competitive gains for noncopper goods in light of the currency appreciation. Chile's export share in Latin America has increased even more markedly, doubling over the past ten years. This is all the more relevant in view of the dynamic market profiles for Chilean exports-i.e., markets where demand growth has been in line with, or faster than, world aggregate import demand. ${ }^{16}$

Working with market shares allows to control for external demand conditions in the absence of sectoral deflators. It can thus be assumed that the country's market share in a specific sector depends on the competitive stance of this country's sector, which itself can be decomposed into two components: a pecuniary source of competitiveness, linked to the RER, and a real component reflecting productivity differentials, the tariff structure, relative prices, and other factors. ${ }^{17}$ Clearly, the two sources are intrinsically related, especially at the aggregate !evel and for relatively lengthy spans. Any disentangling at the sectoral level implicitly assumes that the evolution of the RER is relatively exogenous, as would be the case in a Dutch disease episode.

In the case of Chile, the lack of data precludes a direct estimation of total factor productivity (TFP) at the sectoral level, and the exercise can only attempt to identify the underlying trend in market shares, once the RER effect has been controlled for. ${ }^{18}$ Two caveats apply: first, and as mentioned before, the underlying trend may be driven by other factors besides productivity; second, and more importantly, changes in productivity can themselves be induced by

${ }^{16}$ On this, see Milesi-Ferretti (1998).

${ }^{17}$ The implicit export supply curve is inversely related to the real exchange rate, and shifts with changes in TFP, in the importance of trade integration agreements, etc.

${ }^{18}$ This assumes, for simplicity, that the RER is exogenous to the manufacturing sectors considered, i.e., that it is basically driven by the copper sector. 
movements in the RER, i.e., some sectors can react to a pecuniary loss of competitiveness (induced by an appreciating RER) by improving productivity. There may be a traditional colinearity problem making it difficult to identify both effects separately.

The impact of currency appreciation on the behavior of export market shares by sectors was tested using a seemingly unrelated regression (SUR) approach. Each sector's market share was regressed against a trend ${ }^{19}$ and the real exchange rate. Export market shares were then estimated at a constant exchange rate, ${ }^{20}$ i.e., the market shares that would have prevailed if the exchange rate had not changed in the period being considered. The comparison of actual and estimated markets shares can be used to portray the magnitude of the appreciation effect in the 1990s vis-à-vis the effect of a composite of productivity gains, changes in the tariff structure, and other unspecified factors. In other words, what matters for the actual trend of market shares is not the RER effect per se, but the RER effect in relation to productivity gains. Figure 4 plots the results of this exercise: controlling for RER movements, most sectors present a significant underlying trend (shown as broken lines). However, the extent to which the underlying trends (productivity gains and other factors) and the currency appreciation offset each other varies by sector:

- for wood manufactures, there is a large exchange rate effect that significantly reduces the steep underlying trend; while for animal feed products, the flat underlying trend shifts downward under the effect of appreciation;

- for chemicals, beverages, fish and fish products, fruits and wood chips, and lumber, the RER effect is significant, but the actual trend appears to be driven to an important extent by the underlying trend;

- for metal goods, paper, and pulp, the appreciation does not seem to have a significant impact, i.e., the actual and underlying trends coincide.

In sum, some manufacturing sectors appear to have suffered considerable competitive losses from the appreciation while others seemed to have been quite resilient to it. One reason for this contrasting evolution may be the difference in productivity gains across sectors, which has allowed some of them to cope with the pecuniary loss of competitiveness from the currency appreciation. In addition, there seems to be a negative correlation between the degree of hardship imposed by the RER appreciation and the capital intensity of the export sector. The capacity to adjust the factor intensity and increase the use of capital (a factor increasingly less costly than labor in dollar terms) may have also helped to cope better with the appreciation.

\footnotetext{
${ }^{19}$ The specification allowed the trend to be different in the 1980s and in the 1990s.

${ }^{20}$ Note that the exchange rate determines the abscissa or level of the estimated series, while the slope (the relevant factor for the exercise being performed) remains invariant to the RER chosen.
} 
Because of this effect, it is difficult to find an adequate proxy for productivity at the sectoral level in Chile. Unit labor costs, for example, are driven both by productivity gains and by factor intensity adjustments related to the real appreciation.

\section{Relative unit labor costs}

Although direct indicators of sectoral profitability, effective costs and productivity trends are not available, partial cost or productivity indicators can be constructed. ${ }^{21}$ For instance, a measure of unit labor costs in the manufacturing sector, adjusted to value added, can be constructed for Chile and most Latin American economies. ${ }^{22}$ Figure 5 and Table 5 show that this indicator has increased in Chile (relative to the Latin American average) since approximately the mid-1980s, with a step increase in 1990 that is consistent with significant wage growth at that time, and a soft slope afterwards. Movements in the following years are clearly more dispersed across countries, with very large increases in labor costs relative to Peru and Argentina, but moderate growth or even declines with respect to other Latin American trading partners. This trend holds across several manufacturing sectors, independently of the degree of labor intensity of the sector. Given the context of continued real wage growth and currency appreciation in the 1990s, the evolution of relative ULC appears consistent with sizable productivity gains in the manufacturing sector.

The data on export market shares and unit labor costs trends, however partial, seems to support the hypothesis that overall, manufacturing exports have remained competitive despite the appreciation of the RER in the 1990s, although with different degrees of difficulty across sectors. The appreciation of the currency, partly fueled by a booming copper sector, has prompted noncopper sectors to try to compensate for the RER-induced loss of competitiveness through productivity-induced competitive gains. This pattern of transmission from exchange appreciation to productivity gains is not new and has been emphasized recently in various countries of the region experiencing appreciations, particularly Argentina. In addition,

\footnotetext{
${ }^{21}$ Direct information on labor productivity also is lacking, but labor productivity trends can be roughly inferred from national accounts and employment surveys available since 1986 . These suggest that labor productivity has grown by 2.3 percent a year from 1986 to 1990 , then at a faster rate of 4.7 percent a year. In the late 1980s productivity growth was faster in the nontradable sectors. This pattern was reversed in the $1990 \mathrm{~s}$, with faster productivity growth in the tradable sectors ( 5 percent a year, compared with 4 percent in the nontradable sectors). Higher productivity growth in the tradable sectors was associated with a significant slowdown in employment growth, which declined from 6 percent a year from 1986 to 1990 to barely 0.5 percent a year from 1990 to 1996.

${ }^{22}$ Adjusting to value added allows to capture the impact of changes in other costs such as intermediate inputs and to better approximate trends in the return on capital in the manufacturing sector. It does not, however, reflect the impact of changes in the capital/labor ratio. Data to perform this exercise was only available for Latin American economies.
} 
various manufacturing sectors with access to more capital-intensive technologies appear to have coped better with the appreciation by adjusting their factor intensity to the lower relative cost of capital.

\section{CONCLUding REMARKS AND POLICY IsSUeS}

All indicators confirm that the Chilean peso has appreciated slowly but steadily since the late 1980s. The question that this paper has sought to address is whether this appreciation has inflicted competitive losses on the Chilean economy, or whether it is merely the result of more competitive tradable sectors. As mentioned in Section 2, there are various exchange rate determinants that could serve to explain the observed pattern. In the case of Chile, a number of factors may have been at play besides productivity growth: a strong investment rate for a prolonged period contributing to changing the relative factor endowment and supporting an equilibrium appreciation; the increasing weight of Chile's copper sector as a result of technology-expanded reserves; a sharp increase in the extent of access and availability of foreign capital; and the increase in government spending as a proportion of GDP over the 1990s (likely to have impacted mostly in the shorter term). However, even if these factors imposed a pecuniary loss of competitiveness on noncopper exports, this loss appears to have been compensated by productivity gains, particularly in the manufacturing sector (inverse Balassa effect). In fact, overall manufacturing exports seem to have coped relatively well with the appreciation of the RER.

Nonetheless, a further real appreciation could become problematic since intra-firm productivity gains are likely to face decreasing returns, and factor intensity adjustments toward capital intensive technologies have limits. ${ }^{23}$ This leaves open the question as to future prospects - namely, whether the return to a pattern of persistent currency appreciation would start to impose a severe hardship on noncopper exports. In this context, a number of policy initiatives - which have intrinsic merits on their own-would need to be addressed:

- Measures that can foster further sizable productivity gains, but are not under the direct control of private entrepreneurs include the improvement in infrastructure, particularly with respect to ports, road infrastructure, and sewage; and the upgrading of the regulatory framework to ensure that the pricing of key services (particularly energy and domestic telecommunications) is in line with international standards. The issue of deepening the structural reform process with a view to increasing productivity and competitiveness acquires special importance when considered vis-à-vis the progress of those reforms in Chile's major Latin American trade partners.

\footnotetext{
${ }^{23}$ From a different perspective, Soto and Valdés (1997) found that in 1997 the exchange rate was at or slightly below its equilibrium level, pointing also to the need to carefully monitor future developments.
} 
- A rebalancing in the macroeconomic policy mix (aiming at easing the burden on monetary policy) and possible modifications to the tax treatment of the mining sector could reduce pressures for currency appreciation stemming from strong capital inflows.

- More specifically, in view of the increasing weight of copper in the economy, a careful review of the policy toward the taxation of mining rents may be warranted. Royalty taxes on nonrenewable resources may be justifiable in light of intergenerational redistribution arguments and if nontraditional exporting sectors exhibit sizable (broadly defined) time-tobuild properties. But if there is the potential for mining resources to become obsolete in a relatively short period and if royalties were to significantly deter new projects, then royalties may contribute to lower total fiscal revenues from mining. In that case, a wider income tax base would be more adequate. 
Table 1. Chile: Real Effective Exchange Rates

\begin{tabular}{|c|c|c|c|c|c|c|c|c|c|c|}
\hline & \multicolumn{5}{|c|}{ Index numbers, average $1980-94=100$} & \multicolumn{5}{|c|}{ Annual percentage change $1 /$} \\
\hline & \multicolumn{4}{|c|}{ Real effective exchange rates based on } & \multirow{2}{*}{$\begin{array}{r}\text { Prices of } \\
\text { NT/T }\end{array}$} & \multicolumn{4}{|c|}{ Real effective exchange rates based on } & \multirow{2}{*}{$\begin{array}{r}\text { Prices of } \\
\text { NT/T }\end{array}$} \\
\hline & CPI & WPI & GDP defl. & ULC & & CPI & WPI & GDP defl. & ULC & \\
\hline 1980 & 141.2 & 128.6 & 143.3 & 142.0 & 107.2 & 16.2 & 20.1 & 13.1 & 14.4 & ... \\
\hline 1981 & 169.4 & 141.3 & 161.2 & 217.8 & 120.9 & 19.9 & 9.9 & 12.5 & 53.4 & 12.8 \\
\hline 1982 & 154.3 & 124.8 & 149.3 & 169.1 & 127.3 & -8.9 & -11.7 & -7.3 & -22.4 & 5.3 \\
\hline 1983 & 125.3 & 118.5 & 124.7 & 124.5 & 111.1 & -18.8 & -5.1 & -16.5 & -26.4 & -12.7 \\
\hline 1984 & 122.3 & 119.6 & 116.5 & 119.2 & 106.0 & -2.4 & 0.9 & -6.6 & -4.3 & -4.6 \\
\hline 1985 & 97.7 & 106.5 & 93.6 & 60.4 & 102.7 & -20.1 & -10.9 & -19.7 & -49.3 & -3.1 \\
\hline 1986 & 80.7 & 93.7 & 78.9 & 66.0 & 99.6 & -17.4 & -12.0 & -15.7 & 9.3 & -3.0 \\
\hline 1987 & 75.1 & 89.5 & 76.6 & 63.0 & 92.3 & -6.9 & -4.5 & -2.9 & -4.4 & -7.3 \\
\hline 1988 & 71.3 & 78.4 & 77.4 & 64.9 & 79.4 & -5.1 & -12.4 & 1.0 & 2.9 & -14.0 \\
\hline 1989 & 75.3 & 79.7 & 79.1 & 65.8 & 84.3 & 5.6 & 1.7 & 2.3 & 1.4 & 6.1 \\
\hline 1990 & 72.5 & 76.9 & 73.9 & 69.7 & 86.2 & -3.7 & -3.6 & -6.6 & 6.0 & 2.3 \\
\hline 1991 & 74.5 & 82.9 & 76.6 & 79.1 & 86.6 & 2.7 & 7.9 & 3.7 & 13.4 & 0.4 \\
\hline 1992 & 78.8 & 87.4 & 81.8 & 83.3 & 92.8 & 5.8 & 5.4 & 6.8 & 5.3 & 7.2 \\
\hline 1993 & 80.1 & 86.7 & 82.0 & 86.2 & 101.6 & 1.6 & -0.9 & 0.2 & 3.5 & 9.6 \\
\hline 1994 & 81.7 & 85.4 & 85.0 & 89.2 & 102.1 & 2.0 & -1.5 & 3.7 & 3.4 & 0.4 \\
\hline 1995 & 86.4 & 90.4 & 94.4 & 97.4 & $\ldots$ & 5.7 & 5.8 & 11.0 & 9.2 & $\ldots$ \\
\hline 1996 & 89.4 & 93.8 & 94.7 & $\ldots$ & $\ldots$ & 3.5 & 3.8 & 0.3 & $\ldots$ & $\ldots$ \\
\hline
\end{tabular}

Source: Fund staff estimates.

1/ An increase indicates an appreciation. 


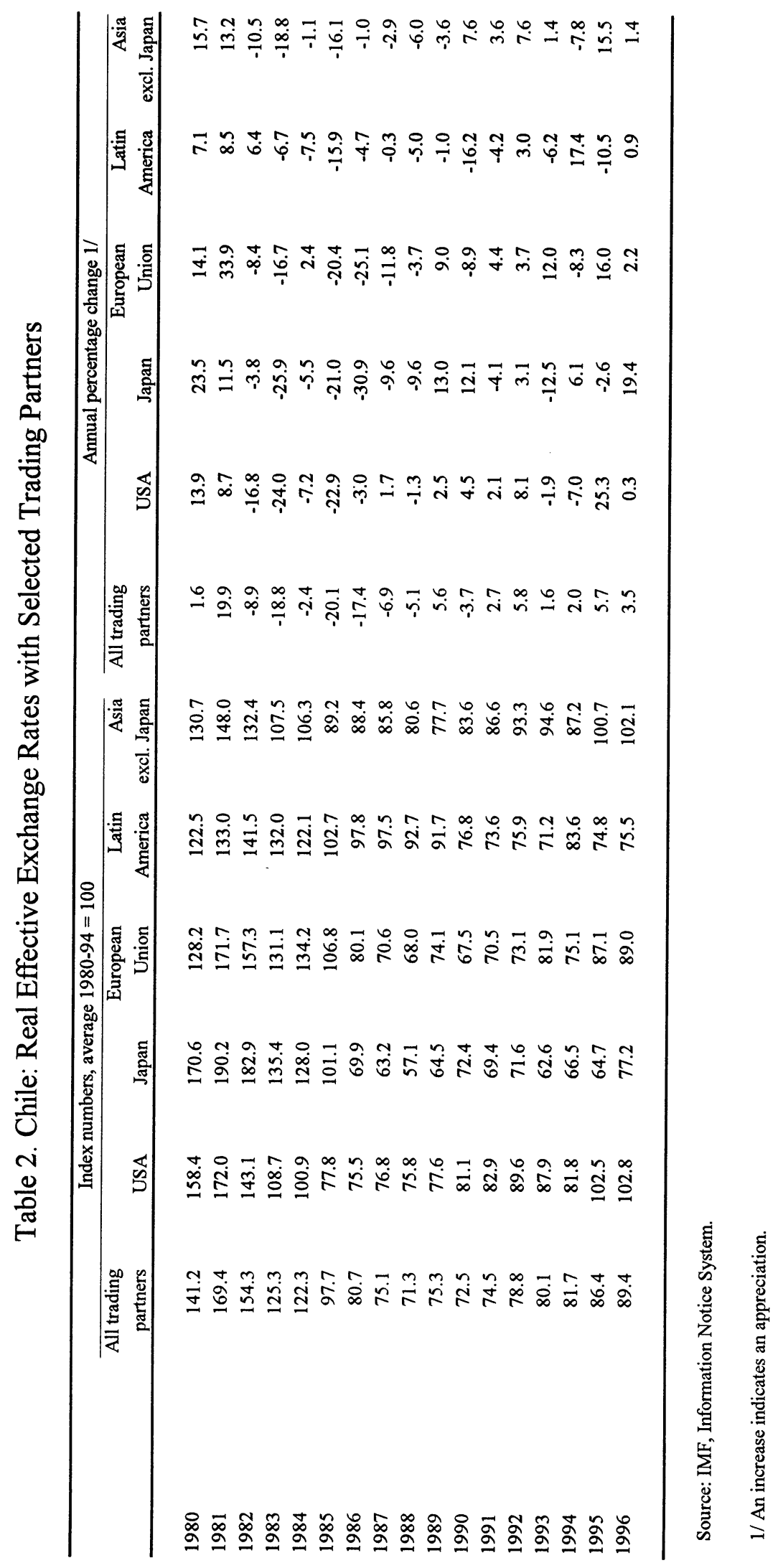


Table 3. Chile: Market Share in Main Export Markets

(Percentage of trading partners' total imports)

\begin{tabular}{|c|c|c|c|c|}
\hline & \multicolumn{2}{|c|}{ Main trading partners } & \multicolumn{2}{|c|}{ Latin America } \\
\hline & Total & Excl. copper & Total & Excl. copper \\
\hline 1980 & 0.28 & 0.09 & 1.07 & 0.50 \\
\hline 1981 & 0.23 & 0.07 & 0.67 & 0.31 \\
\hline 1982 & 0.25 & 0.09 & 0.74 & 0.27 \\
\hline 1983 & 0.29 & 0.10 & 0.85 & 0.49 \\
\hline 1984 & 0.24 & 0.10 & 0.97 & 0.50 \\
\hline 1985 & 0.24 & 0.10 & 0.96 & 0.49 \\
\hline 1986 & 0.23 & 0.11 & 1.18 & 0.65 \\
\hline 1987 & 0.24 & 0.12 & 1.37 & 0.68 \\
\hline 1988 & 0.29 & 0.13 & 1.18 & 0.52 \\
\hline 1989 & 0.32 & 0.14 & 1.41 & 0.77 \\
\hline 1990 & 0.29 & 0.13 & 1.27 & 0.82 \\
\hline 1991 & 0.29 & 0.15 & 1.27 & 0.87 \\
\hline 1992 & 0.31 & 0.17 & 1.16 & 0.81 \\
\hline 1993 & 0.30 & 0.17 & 1.17 & 0.92 \\
\hline 1994 & 0.31 & 0.18 & 1.29 & 0.97 \\
\hline 1995 & 0.37 & 0.20 & 1.47 & 1.04 \\
\hline 1996 & 0.37 & 0.20 & $\ldots$ & $\ldots$ \\
\hline
\end{tabular}

Source: Fund staff estimates from the United Nations trade database. 
Table 4. Unit Labor Costs in U.S. dollars (Value-Added Adjusted) in the Manufacturing Sector (Annual percentage change)

\begin{tabular}{|c|c|c|c|c|c|c|c|c|c|}
\hline & Chile & Argentina & Bolivia & Brazil & Colombia & Mexico & Peru & Uruguay & Venezuela \\
\hline 1981 & 25.5 & -4.1 & -25.3 & 11.0 & -4.2 & 2.1 & -6.1 & -10.7 & 2.3 \\
\hline 1982 & -16.3 & -15.3 & -65.5 & 4.5 & 10.0 & -1.3 & 4.6 & -7.5 & -3.6 \\
\hline 1983 & -12.2 & 20.9 & 233.9 & -15.9 & 2.1 & -30.1 & 3.6 & 11.9 & -0.9 \\
\hline 1984 & -5.5 & 24.5 & 77.9 & -8.6 & 2.5 & -10.4 & -9.0 & -24.8 & -4.6 \\
\hline 1985 & -8.7 & -22.6 & -37.4 & 17.8 & -13.1 & -1.2 & 0.6 & 19.0 & -4.0 \\
\hline 1986 & 29.1 & -16.1 & -41.5 & -0.1 & 2.0 & -4.8 & 9.7 & 7.1 & -1.9 \\
\hline 1987 & 1.4 & 18.4 & 81.3 & -8.1 & -6.6 & -6.0 & 0.3 & 4.0 & -9.3 \\
\hline 1988 & 6.0 & 7.4 & -22.7 & 6.0 & -5.6 & -2.8 & -11.0 & 4.2 & -0.6 \\
\hline 1989 & 1.6 & -14.5 & 7.4 & -6.6 & -4.4 & -2.5 & -21.3 & -12.6 & -20.3 \\
\hline 1990 & 16.9 & -3.9 & -12.5 & -6.5 & -5.3 & -0.8 & -22.7 & -13.0 & 3.6 \\
\hline 1991 & 1.4 & -27.5 & -5.2 & -7.9 & -0.8 & 1.4 & -18.0 & -3.1 & 14.2 \\
\hline 1992 & -2.0 & -18.7 & 13.5 & 18.1 & -8.1 & -9.7 & -43.3 & -1.1 & -13.5 \\
\hline 1993 & -8.9 & $\ldots$ & $\ldots$ & -2.8 & -2.2 & $\ldots$ & -2.1 & -6.7 & -0.9 \\
\hline 1994 & 2.8 & $\ldots$ & $\ldots$ & -0.7 & $\ldots$ & $\ldots$ & $\ldots$ & -12.5 & $\ldots$ \\
\hline
\end{tabular}

Source: Fund staff estimates from ECLAC's database of industrial surveys. 
Figure 1. Chile: Evolution of the Real Effective Exchange Rate

(Index numbers, average 1980-94=100)
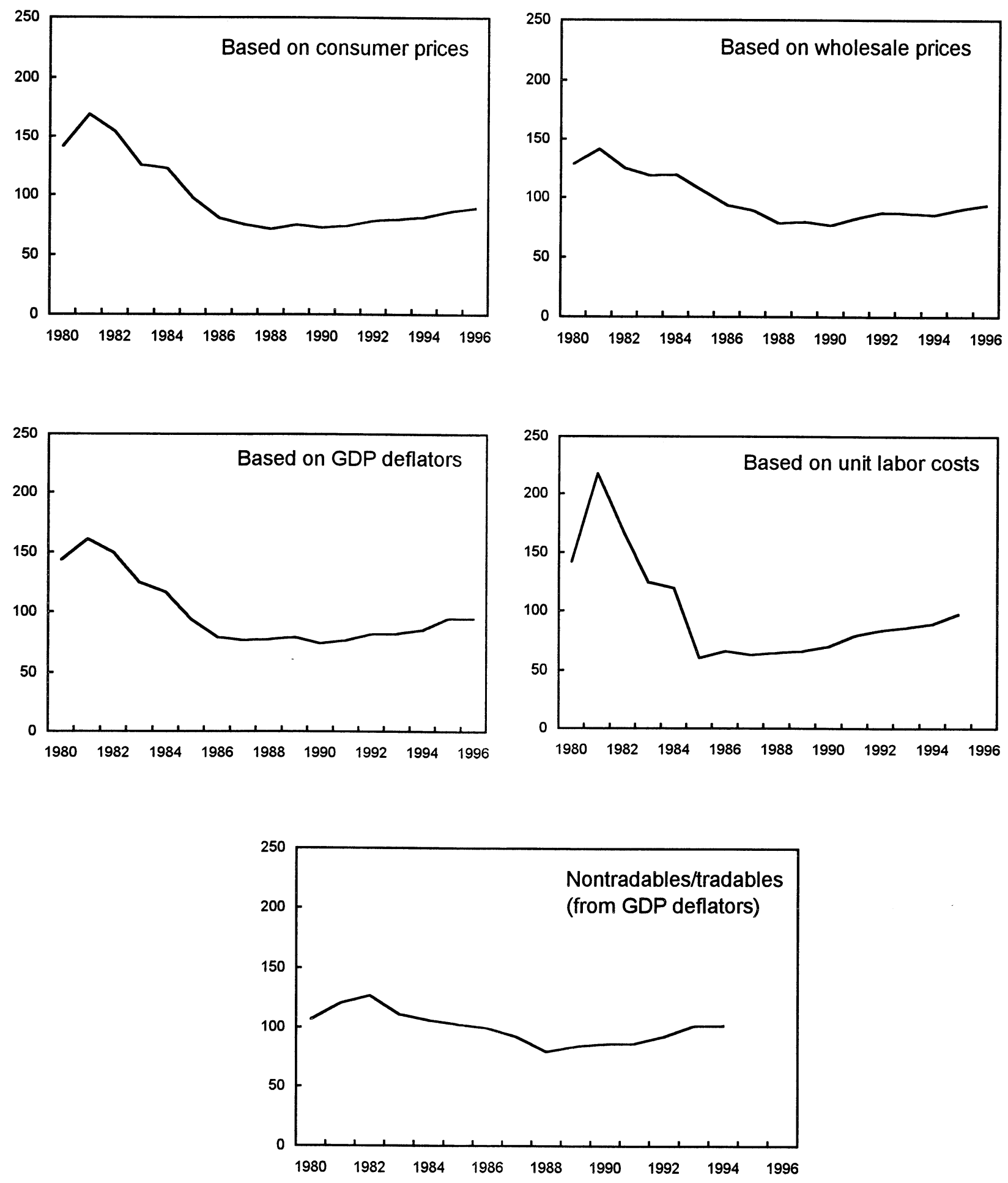

Source: Staff estimates. 
Figure 2. Chile: Real Effective Exchange Rates with Selected Trading Partners (Index numbers, average 1980-94=100)
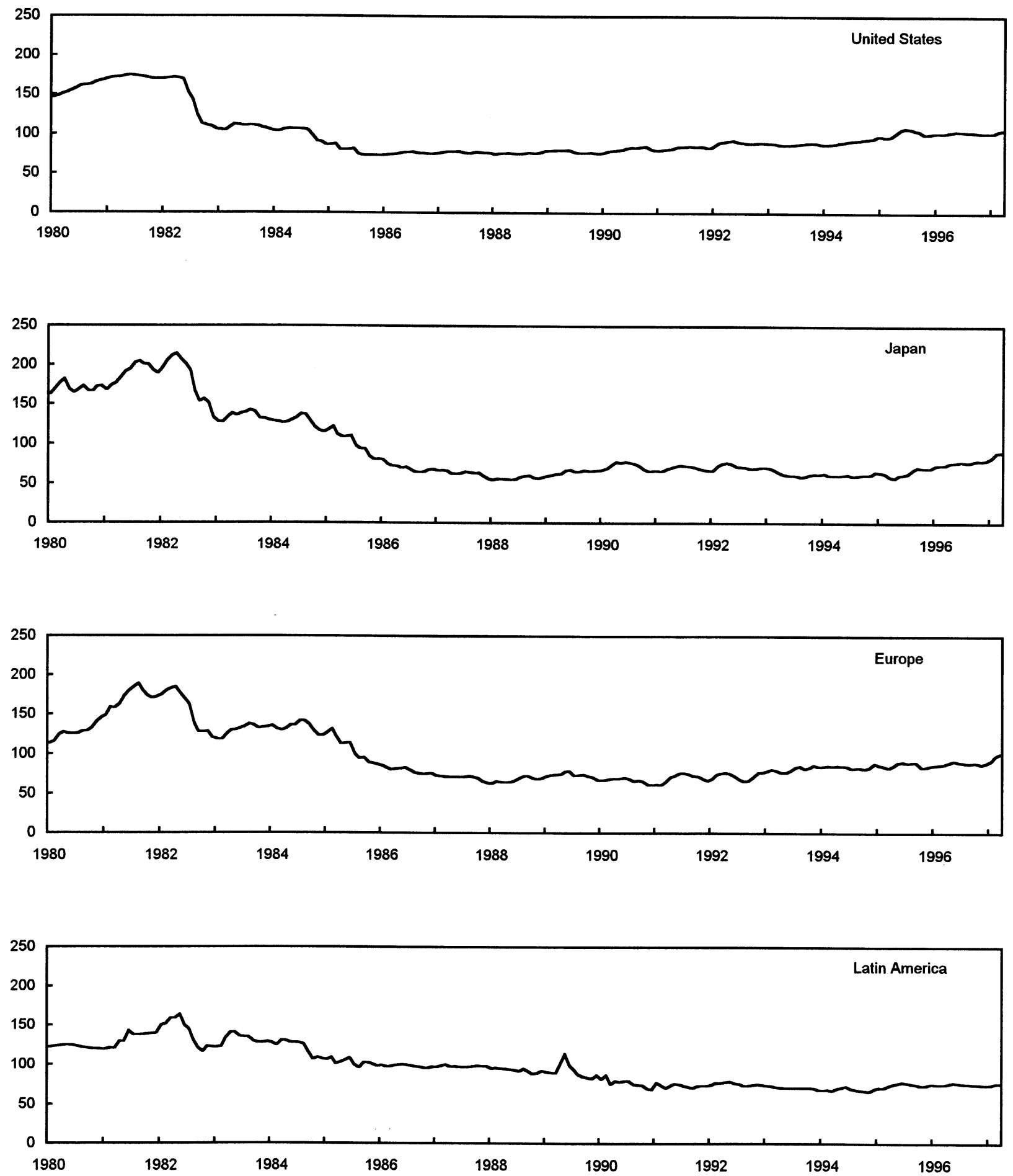

Source: Information Notice System of the IMF. 


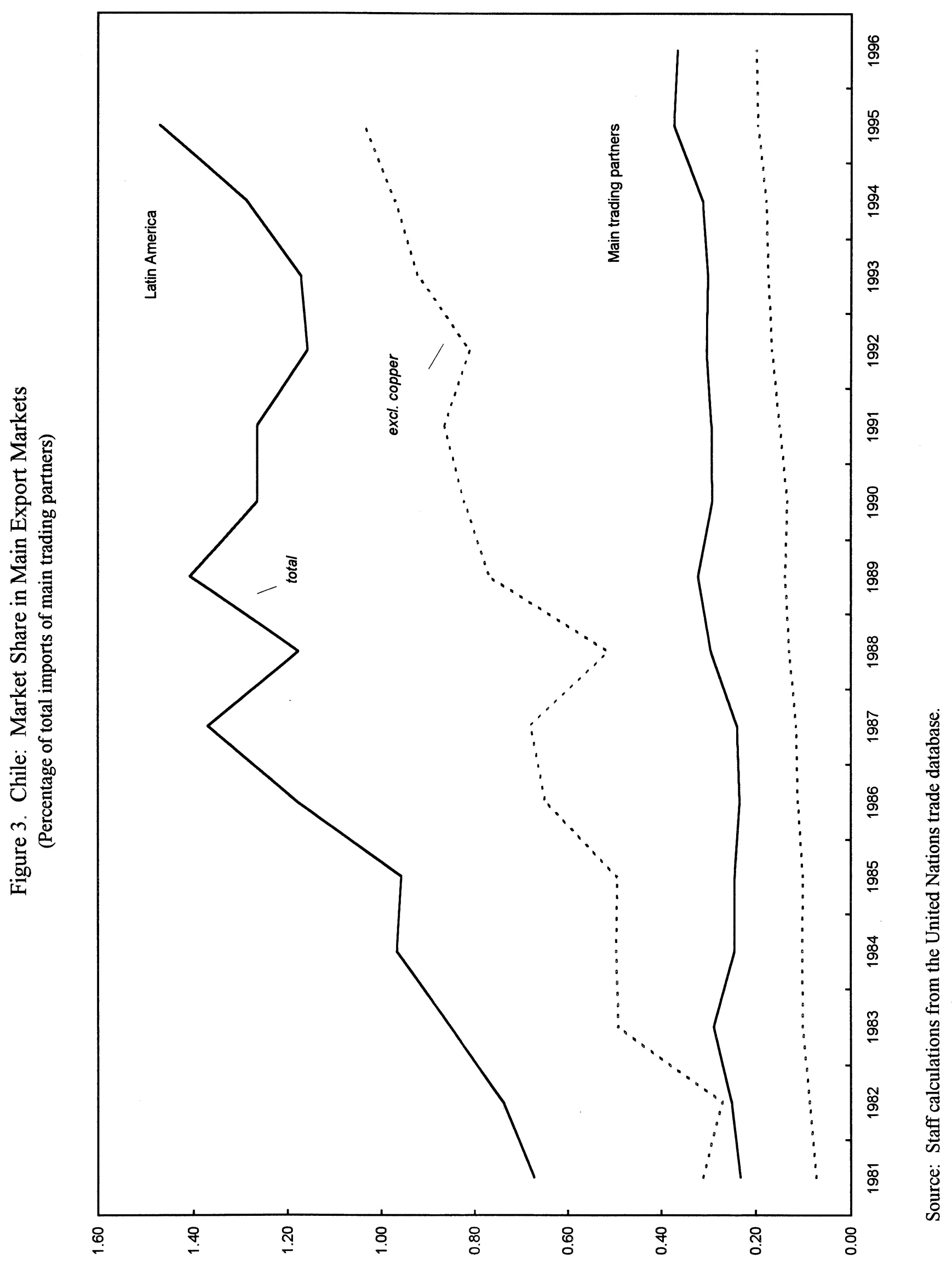


Figure 4: Export Shares and Export Shares at Constant Exchange Rate (in logs)

Beverages

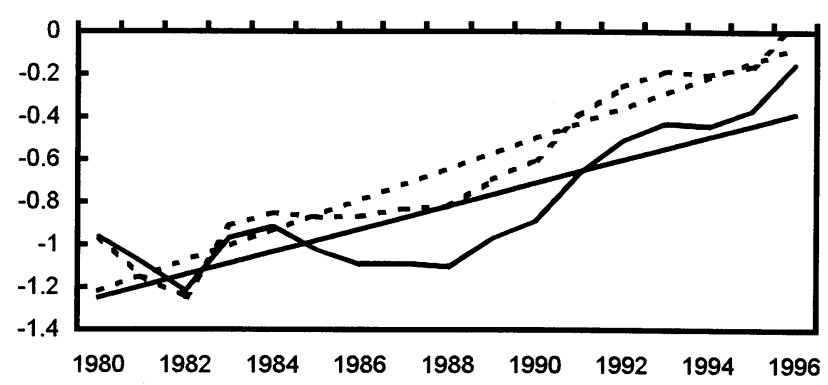

Animal Feed

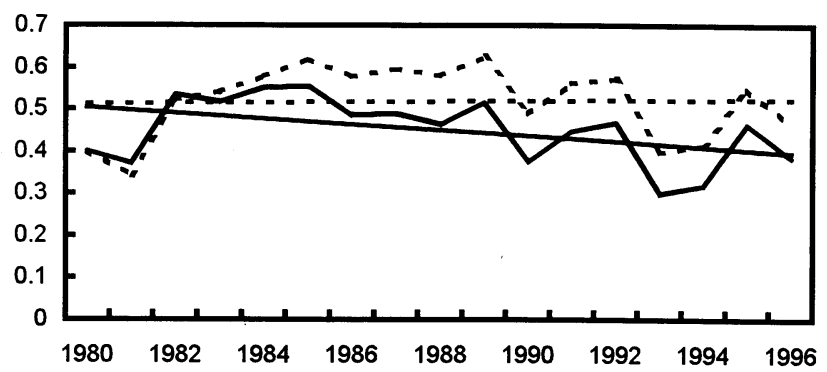

Fruits

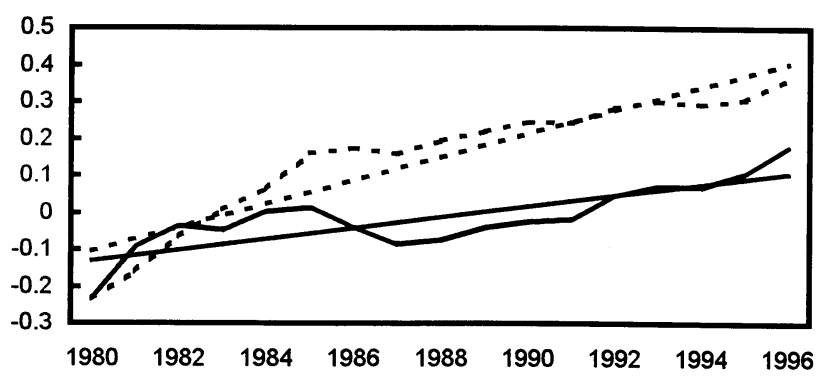

Wood Manufactures

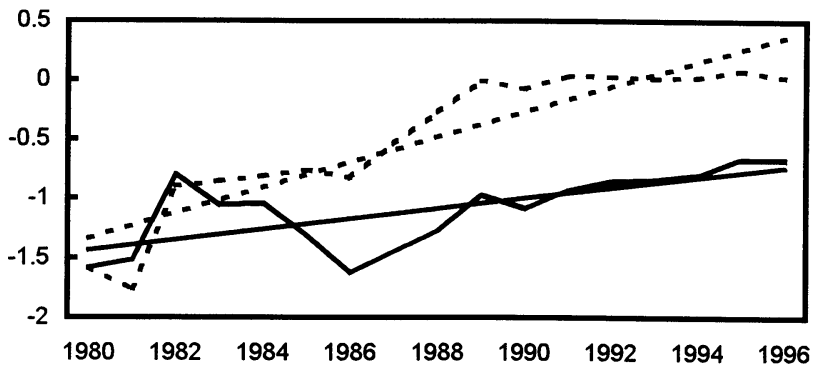

Chemicals

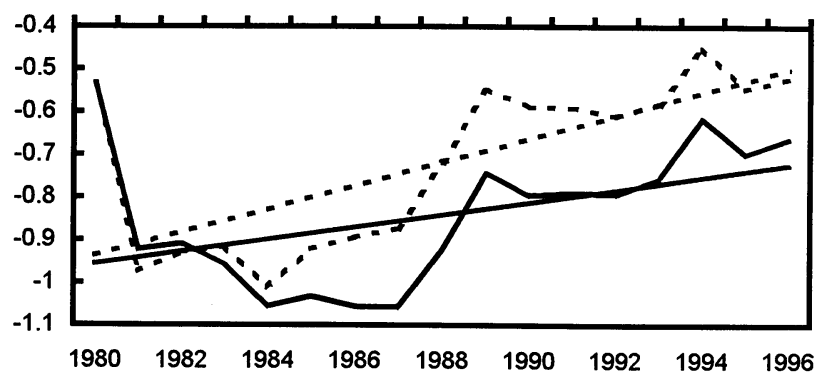

Fish and Fish Products

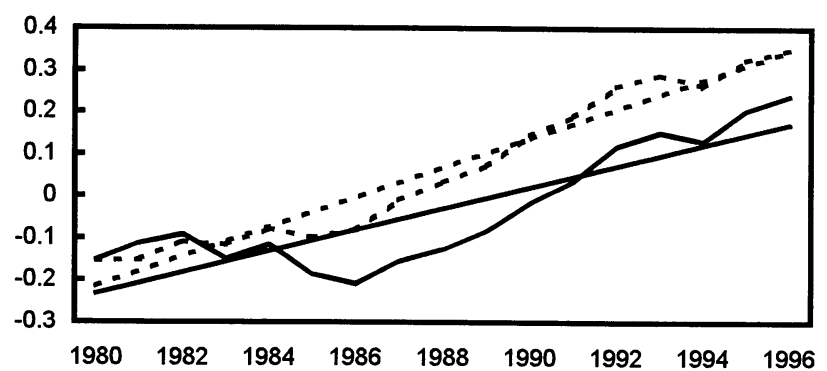

Metal Products

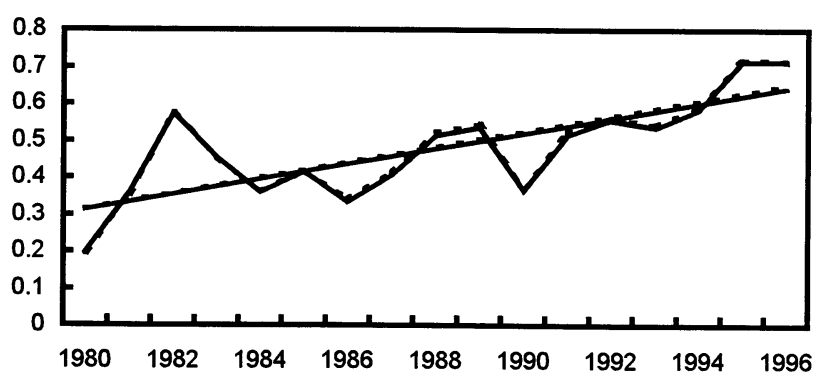

Wood Lumber and Chips

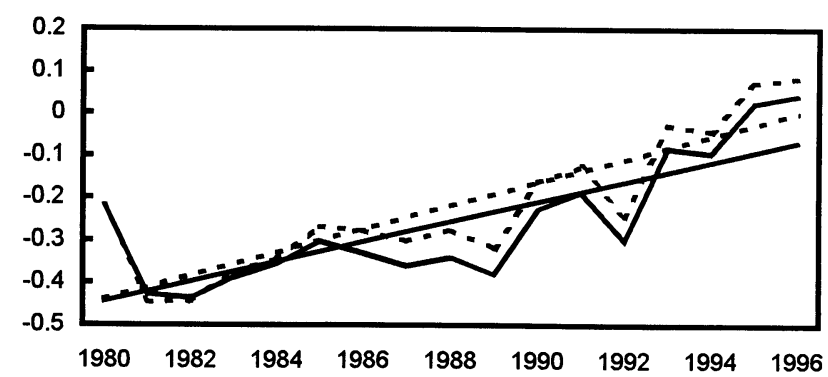

Solid line: actual market shares and corresponding trend

Broken line: market shares at constant exchange rate and corresponding trend 
Figure 4: Export Shares and Export Shares at Constant Exchange Rate (in logs)

Paper Products

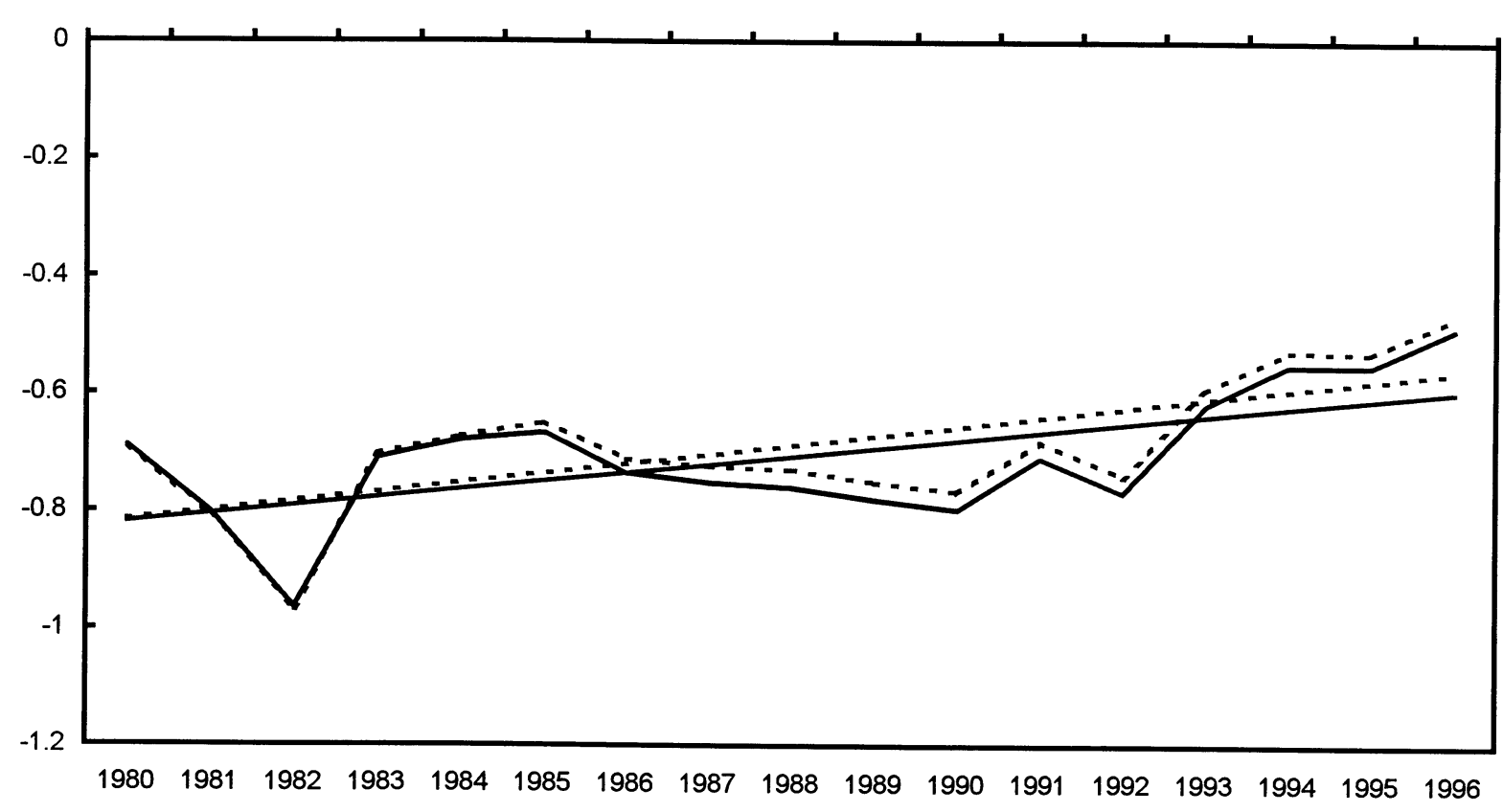

Pulp Products

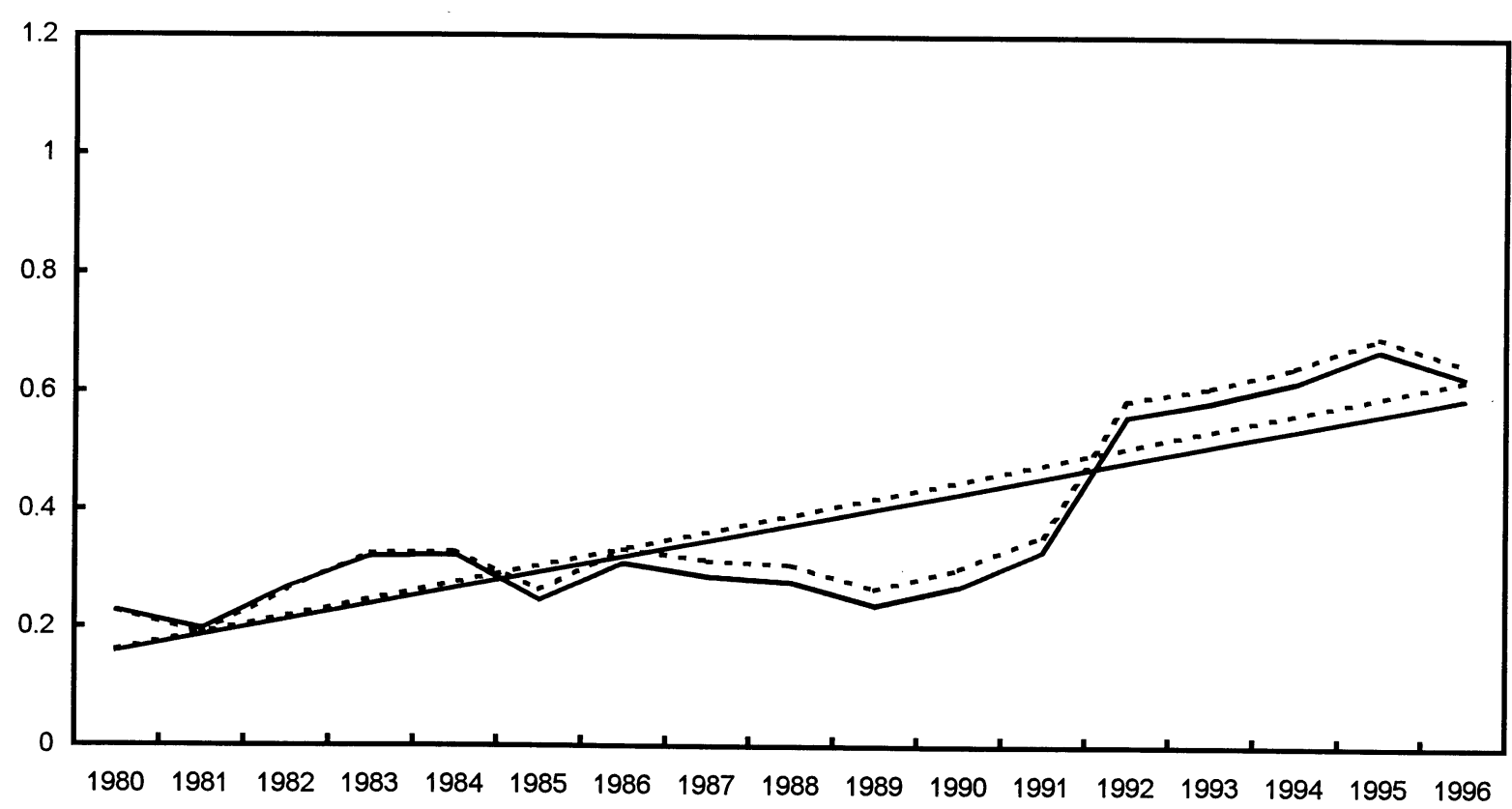

Solid line: actual market shares and corresponding trend

Broken line: market shares at constant exchange rate and corresponding trend

Source: Fund staff calculations. 
Figure 5. Chile: Relative Labor Costs in the Manufacturing Industry 1/ (Value-added adjusted; in U.S. dollars)
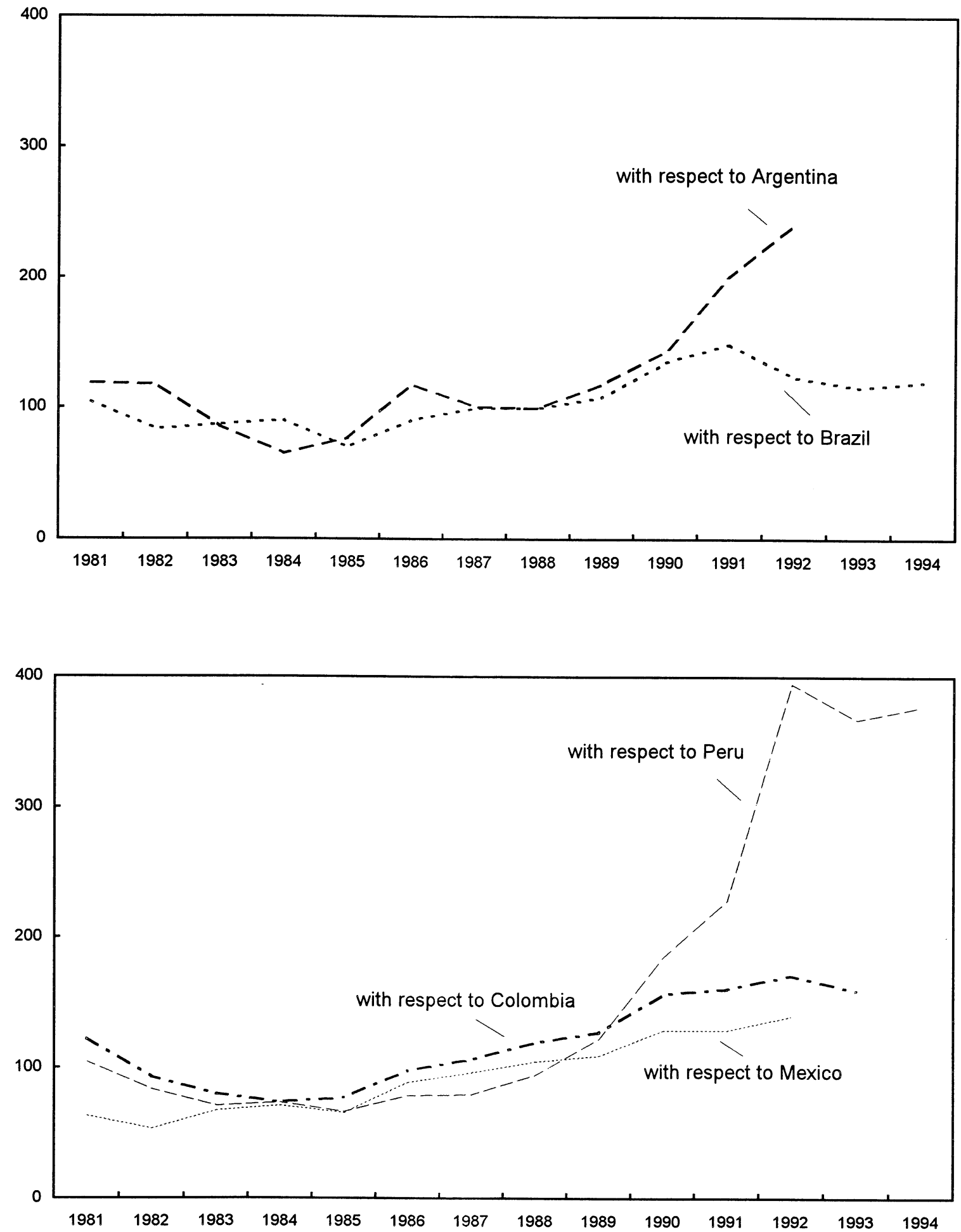

Source: Staff calculations, from ECLAC's database of industrial surveys.

1/ Ratio of Chile's unit labor costs to a trading partner's unit labor costs. 


\section{References}

Arellano, S. and F. Larraín, "Tipo de Cambio Real y Gasto Público: Un Modelo Econométrico para Chile," Cuadernos de Economía, 98, April 1996.

Armington, P. S., "A Theory of Demand for Products Distinguished by Place of Production," IMF Staff Papers, International Monetary Fund, Vol. 16, 1, March 1969.

Balassa, B., "The Purchasing-Power-Parity Doctrine: A Reappraisal," Journal of Political Economy, Vol. 72, December 1964.

Bergstrand, J. H., "Structural Determinants of Real Exchange Rates and National Price Levels: Some Empirical Evidence," American Economic Review, Vol. 81, March 1991.

Bhagwati, J., "Why are Services Cheaper in the Poor Countries?," Economic Journal, 94, June 1984.

Calvo, G., L. Leiderman and C. Reinhart, "Capital Inflows to Latin America: The Role of External Factors," IMF Staff Papers, International Monetary Fund, Vol. 40, 1, March 1993.

Corden, W. M. and J. P. Neary, "Booming Sector and De-Industrialization in a Small Open Economy," Economic Journal, Vol. 92, December 1982.

De Gregorio, J., A. Giovannini and T. H. Krueger, "The Behavior on Nontradable Goods Prices in Europe: Evidence and Interpretation," IMF Working Paper, 93/45 (Washington: International Monetary Fund), May 1993.

De Gregorio, J., A. Giovannini and H. C. Wolf, "International Evidence on Tradables and Nontradables Inflation,” NBER Working Paper \#4438, August 1993.

Edwards, S., Real Exchange Rates, Devaluation and Adjustment: Exchange Rate Policy in Developing Countries, Cambridge, Mass.: MT Press, 1989.

Frankel, J. and K. Froot, "Chartists, Fundamentalists and Trading in the Foreign Exchange Market," American Economic Review, Vol. 80, May 1990.

Harberger, A. C., "Economic Adjustment and the Real Exchange Rate," in Economic Adjustment and Exchange Rates in Developing Countries, Edwards S. and L. Ahmed ed., Chicago and London: University of Chicago Press, 1986.

Harrod, R. F., International Economics, Cambridge Economic Handbooks, London: Nisbet \& Cambridge University Press, chap. IV, 1933. 
Hsieh, D., "The Determination of the Real Exchange Rate: The Productivity Approach," Journal of International Economics, 12, May 1982.

Lipschitz, L. and D. McDonald, "Real Exchange Rates and Competitiveness: A Clarification of Concepts and some Measurements for Europe," IMF Working Paper 91/25 (Washington: International Monetary Fund), March 1991.

Marsh, I.W. and S. Tokarick, "Competitiveness Indicators: A Theoretical and Empirical Assessment," IMF Working Paper 94/29 (Washington: International Monetary Fund), March 1994.

Milesi-Ferretti, G. M. and S. Micossi, "Real Exchange Rates and the Prices of Non-Tradable Goods," in Inflation and Wage Behavior in Europe, De Grauwe P., S. Micossi and G. Tullio, ed., Oxford: Claredon Press, 1996.

Milesi-Ferretti, G. M., "External Sustainability: A Study of Chile”, mimeo, International Monetary Fund, 1998.

Neary, P., "Determination of the Equilibrium Real Exchange Rate," American Economic Review, Vol. 78, March 1988.

Samuelson, P., "Theoretical Notes on Trade Problems," Review of Economics and Statistics, Vol. 46, March 1964.

Schmidt-Hebbel, K. and L. Servén, "Fiscal Adjustment and the Exchange Rate under Rational Expectations in Chile," mimeo, World Bank, October 1995.

Soto, C. and R. Valdés, "Desalineamiento del Tipo de Cambio Real en Chile," mimeo, Banco Central de Chile, October 1997.

Turner, P. and J. Van't dack, "Measuring International Price and Cost Competitiveness," BIS Economic Papers No.39, November 1993.

Wickham, P., "A Cautionary Note on the Use of Exchange Rate Indicators," IMF Papers on Policy Analysis and Assessment 93/5 (Washington: International Monetary Fund), March 1993.

Zanello, A. and D. Desruelle, “A Primer on the IMF's Information Notice System," IMF Working Paper 97/71 (Washington: International Monetary Fund), May 1997. 